\title{
Waqf empowerment for the autonomy of Islamic boarding school (pesantren); study of modern Islamic boarding school (pondok) Tazakka Batang
}

\author{
Subhi Mahmassani \\ Tazakka Waqf Foundation, Indonesia
}

\begin{abstract}
Purpose - This study aims to study waqf instrument developed by modern Islamic boarding school (pondok) Tazakka, Batang.

Method - This study is a qualitative field research, which utilizes observation, interview, and documentation. The character of this research is descriptive analysis.

Result - Modern pondok of Tazakka uses at least six different waqf program as a financial source of their activities. These programmes are asset waqf, cash waqf, productive waqf, benefits waqf, profession waqf, and transfer of rights waqf. The programmes help the pondok to be more autonomous and able to provide various benefits for the scholars of the pondok and the people surround it.
\end{abstract}

Implication - This research gives illustration of waqf management in an Islamic boarding school. By understanding the mechanism of the waqf management, hopefully Islamic boarding schools in Indonesia able to empower themselves better.

Originality - A lot of Islamic boarding schools use waqf for his research is among the few researchs which taking a perspective of empowering religious social organization in Indonesia.

Keywords: waqf management, modern Islamic boarding school 


\section{Introduction}

Economically independent is an economic principle that must JIEMB $\mid 2$ be held by Islamic boarding schools or pondok pesantren. In the Mu'adalah Mu'allimin of Pondok Modern Gontor, for example, the principle of economic independence is contained in five sacred principles called "Panca Jiwa". Panca Jiwa or five fundamental principles that must be held by Islamic boarding schools are the spirit of sincerity, the spirit of simplicity, the spirit of self-reliance, the spirit of ukhuwah Islamiyah, and the spirit of freedom. This spirit of independence implies the principle of economic independence of the pesantren.

The need for pesantren to be economically independent is based on several reasons. First, in order that the pesantren does not depend on other people or institutions for their survival so that there is no intervention from external parties to the internal policies of the pesantren. Second, the pesantren can survive. As an educational institution rooted in the community, pesantren is very dependent on funding from the community. If the pesantren is abandoned by the community, it may decline or collapse due to funding problems. Third, pesantren must be economically independent so that they remain above all groups and socio-political forces outside the pesantren, maintaining the neutrality and objectivity of education. Finally, pesantren must be economically independent so that they can freely develop themselves without fear of stagnating along the way if they lack or lose funding sources from the government or the community.

There are many ways that Islamic boarding schools can do to achieve a level of economic independence. Hafidh and Badrudin (2018) argued that pesantren could achieve economic independence by establishing livestock, fisheries, mining, agriculture and waste management businesses. In another record, economic independence of pesantren also can be achieved with the instruments of establishing business units such as bookstores, iron shops, ice factories, bakeries, and forest management. Meanwhile, according to $\mathrm{KH}$. Anang Rikza Masyhadi (in interview), in addition to creating business units as mentioned above, it can also be done by developing waqf instruments. 
In the Islamic tradition, there are many financial-economic institutions, for example zakat, donations, alms, baitul mal wattamwil, and shari'ah banking. Many pesantrens have developed financial-economic institutions for the benefit of the pesantrens. An example is waqf.

Almost all pesantrens use waqf institutions for their financial interests. However, although waqf as one of the financial and economic institutions in the Islamic tradition has been practiced by many pesantrens, in fact, only a few of the pesantrens have put all their efforts into developing waqf instruments to strengthen the economic independence of the pesantrens, as for example the one developed by Pondok Modern Tazakka.

Pesantrens only treat waqf as a secondary source of income. This is not the case with Pondok Modern Tazakka, where the waqf instrument is engineered in such a way as to become the primary source of income for the pesantren, in addition to the zakat, donation and alms instruments. Based on this background, this research discusses the waqf instrument developed by Pondok Modern Tazakka, which aims to achieve the economic independence of the pesantren with the formulation of research problems as follows:

1. How is the waqf instrument developed by Pondok Modern Tazakka to strengthen its economic independence?

2. What is the strategy of the Waqf Institution of Pondok Modern Tazakka in collecting and developing waqf assets to increase the productivity of its waqf value?

\section{Literature review}

Some previous researches on waqf have been conducted and are presented here as differentiators and to show the authenticity of the current research.

Huda's dissertation in 2012 entitled "Management of Waqf in a Fundrising Perspective (translated) (A Study on Raising Waqf at the Hasyim Asy'Ari Foundation, Tebuireng Islamic Boarding School, Jombang, Yayasan Badan Wakaf, Islamic University of Indonesia, Yogyakarta, and AI-Falah Social Fund Foundation, Surabaya)" explored the form of waqf fundraising, namely; First, fundraising waqf funds from readily available sources such as individual communities, government and companies. Second, fundraising by making existing waqf assets productive, such as renting shops, etc. 
Third, fundraising by empowering the distribution of aspirants from endowments such as education and the economy.

The second study is Hilmi's Dissertation in 2009 on Dynamics of Management of Cash Waqf (translated) (Study of the Behavior of Cash Waqf Management after the Enactment of Law No. 41 of 2004 on Waqf) which is a phenomenological qualitative research on sociolegal studies. The results of this study found that: (1) the management of cash waqf by the nine cash waqf management institutions studied had different understanding and levels of regulatory acceptance, (2) cash waqf according to the design of the law received less response from the public. The development of cash waqf management tends to be different because cash waqf which is understood to be transformed into social or productive waqf assets develops rapidly in society.

The book entitled Productive Waqf Management (translated) by Dr. Rozalinda M, Ag. explains about the guidelines for managing waqf assets productively, starting with a description of the real condition of waqf in Indonesia, waqf in the dynamics of Islamic law, professional waqf nazhir, recording and registration of waqf assets, managing fundamentals and their distribution. It ends with an explanation of the development of waqf in the international world and the development of productive waqf management in Indonesia.

The third study was Simbolon's 2016 thesis entitled "Endowments in the Perspective of Fiqh and Law No. 41 of 2004 and Its Implications for Empowerment of the People." It explored the term waqf in two perspectives, namely the perspective of fiqh and formal legal law as stipulated in Law no. 41 of 2004. The results give rise to the conclusion that the basis of Law Number 41 of 2004 provides a time limit for waqf for fixed assets, namely: based on juridical considerations. Basically, the substance contained in the provisions of Article 1 paragraph (1) of Law Number 41 of 2004 is the beneficial value of waqf assets. So, the principle of the benefit of the waqf object becomes the most relevant basis for the existence of the object itself. The logical consequence of long-term (temporary) waqf is that more and more people donate their assets, because eternal waqf is synonymous with eliminating ownership rights. With the increasing number of people who are interested in waqf, the property of waqf will also increase, so that it is possible to develop it optimally to realize the welfare of the society. 
The fourth was Wahyudi's research in 2016 entitled "Productive Waqf Management (Analysis Study at Baitul Mal in Kudus Regency)." It explored the management of collection, development, utilization and reporting of productive waqf. This is a qualitative research with data collection methods through observation, interviews and documentation. This research concludes that productive waqf is part of the management system. It can be seen that if human resources in managing waqf are skilled and professional, of course the productivity in collecting and developing waqf will increase and can cover a wider use and distribution of waqf assets, so that the Baitul Mal institution engaged in waqf development will be able to have a large contribution to the society in the fields of education, economy, health and other social assistance.

Another research was conducted by Munir in 2015 entitled "Optimizing Productive Waqf Empowerment". It examined the productive waqf practice from the point of view of sharia law. The results of this study illustrate that waqf is still widely practiced according to the objectives of the waqf. If you want to be more optimal in mobilizing productive waqf, you certainly have to increase the maximum socialization of nazhir in introducing the program of productive waqf that is carried out.

Based on the researches above, it can be seen that there are several similarities in several aspects. First, in terms of major themes, the five studies above take waqf as the main study. Second, in the research of Wahyudi (2016) and Munir (2015), even the specific themes also have similarities with the current research, that is regarding productive waqf. Third, their dissertations also have an aspect of the research carried out more in the nature of field research. However, although there are similarities in several aspects, this research has differences which become an aspect of originality in the basis of research implementation. The difference lies in the object of research which is the fulcrum for conducting the research, namely taking the Pondok Modern Tazakka Batang as the object. Second, this research is trying to explain the concept of the waqf instrument development of Pondok Modern Tazakka Batang in order to strengthen its economic independence. Third, it describes the uniqueness of the development of waqf instruments in Pondok Modern Tazakka Batang. So, on this basis, it is definitely the main 
reason for the author to be a consideration in continuing the research in a more in-depth and comprehensive manner.

\section{Waqf}

Waqf in an Islamic perspective can be used as a means of JIEMB I 6 empowering economic welfare for the wider community. Currently, there are still many obstacles to the development of waqf in the future, one of which is the narrow understanding of waqf and the less advanced management of nazir related to waqf property which is considered limited by regulations.

Generally, there are two waqf practices (Ghazaly, Ihsan, \& Shidiq, 2015) which are family waqf (al-waqfu al-Ahliyyu or aldzurriyyu) and general waqf (al-waqfu al-khairiyyu). Waqf ahly or dzurry is waqf intended for the interests and social security in the family environment, namely the environment of one's own relatives or to individuals (Sabiq, 1983; 2007). For example, if someone donates a piece of land to their children, then to their grandchildren, then the waqf is valid and those who are entitled to benefit from it are those appointed in the waqf statement.

In terms of worship, it will be declared valid if the terms and conditions are fulfilled. Likewise in terms of waqf, waqf is declared valid when the terms and conditions have been fulfilled. There are four terms and conditions of waqf:

1. Wakif; people who have waqf are called wakif.

2. Mauquf bih; means the commodity or object that is donated.

3. Mauquf 'Alaih; means the party receiving the waqf or the allotment of the waqf.

4. Shighat; means statement or pledge of the wakif.

\section{Islamic boarding school (pesantren)}

Pesantren is one of the Islamic education systems in Indonesia which has its own characteristics. The definition of pesantren itself has varied meanings, but in essence it contains the same meaning. The word pesantren comes from the Sanskrit language which gets its own form and meaning in Indonesian. The origin of the word san means a good person (male), followed by tra means helping, santra means a kind person who likes to help. Pesantren means a place to cultivate human beings to become good people (Mursyid, 2011). 


\section{Development and economics autonomy}

The development of waqf instruments is a method and deliberate action of making existing waqf instruments become more numerous, bigger, wider, and more advanced. The meaning of "development" in the book Waqf Accounting published by the Sharia Accounting Standards Board, Indonesian Institute of Accountants (2018) is

"The results of the management and development of waqf assets constitute additional economic benefits in the form of additional assets sourced from existing waqf assets. The results of the management and development of waqf assets are in addition to existing waqf assets" (translated)

In this explanation, it is implicitly said that the development of waqf assets means the addition of economic benefits in the form of additional assets that come from a set of existing waqf, which results in addition to the existing waqf assets. So, based on the information from the Indonesian Accounting Association above, what is meant by the development of waqf instruments here includes the addition of waqf assets which have an impact on the additional economic benefits of the waqf assets.

Based on the definitions by Robbins (2017), Advani (2014), and Tharp, Sjuggerud, and Barton (2004), what is meant by economic / financial independence in this paper is:

1. Has no economic problems so that you can feel peace in your heart, feel comfortable, feel free, not be swayed by financial problems, have a stable financial position so that you are not affected by any financial problems.

2. Have wealth that is not limited by time (throughout life), continues to be rich, and is financially secure.

3. No longer need to try hard to make money, no longer earn money hard, but be able to control and control money, have liabilities and wealth that is not limited by time, is not limited by space, is not limited by ability, and is not limited by financial problems.

To measure whether a pesantren has achieved a high or low level of economic/financial independence, the concept of "financial freedom number" proposed by Tharp et al. (2004) is used. If the pesantren has a liability income each month that is greater than the 
expenses incurred each month, then the pesantren has economic independence. On the other hand, if a pesantren has monthly expenses that are greater than the monthly liabilities, then the pesantren does not yet have economic/financial independence.

JIEMB | 8 Empowerment of waqf for the independence of the pesantren

Qahaf (2006) said that productive waqf is moving assets from consumptive to productive efforts and investment in the form of production capital that can produce and produce something that can be used in the future, either by individuals, groups or by the public. Thus, productive waqf is an activity of saving and investing simultaneously.

Law Number 41 of 2004 concerning Waqf is a regulation that aims to strengthen the position of waqf. First, it is elevated from a Government Regulation and a Presidential Instruction to become a Law. Second, the scope of waqf objects, which were initially limited to land and objects (empirical, concrete), was expanded to include intangible objects (including rights). Third, in order to mobilize waqf as a medium for creating public welfare, the government expands the waqf law enforcement apparatus, including the formation of the Indonesian Waqf Board (BWI) (Mubarok, 2008).

\section{Methodology}

Since this research was conducted to know the development of waqf instruments for the independence of Pondok Modern Tazakka Batang, in general it was carried out in accordance with the findings in the field. After the required data have been collected, it will be possible to identify the problem and solve the problem.

This research took place in Pondok Modern of Tazakka educational institution in Sidayu Village, Bandar District, Batang Regency, Central Java. The nature of this research is descriptive analysis, which provides a description of waqf and the practice of developing waqf for economic independence of Pondok Modern Tazakka Batang. The existing data were then analyzed to find conclusions.

The data were obtained directly from the research subject as a source of information through observation, face-to-face interviews with the leaders of the Pondok Modern Tazakka Batang, the Chairman of the Foundation as a waqf nazhir at the Tazakka Waqf 
Institution to get more information so that its validity can be accounted for.

Data were also obtained from other complementary sources such as books that are directly related to the research material, the Tazakka Waqf Institution annual report, literature studies, citing and reviewing laws and regulations, documents, and other literature relating to the issues discussed. The method used to answer research problems requires accurate data in the field and must be in accordance with the object under study.

Data collection techniques are carried out through an observation, accompanied by notes on the state or behavior of the target object. Observations were made to obtain an overview of waqf at Pondok Modern Tazakka. The researchers feel the need to see, listen or feel for themselves by using observational data collection techniques.

This research also used interview method to gather data. The researchers had previously prepared a draft as a guide in the interview and then asked the informants. This interview was conducted semi-structured where the interview could develop according to the needs of the data obtained in the field. This interview was conducted by researchers to the Board of Directors and the ZISWAF Board at Pondok Modern Tazakka Batang.

\section{Results and discussion}

\section{Profile of modern pondok Tazakka}

Pondok Modern Tazakka Batang is an educational institution located in Sidayu Village, Bandar District, Batang Regency, Central Java Province. This Islamic boarding school has been officially registered at the Office of the Ministry of Religion of the Republic of Indonesia in Batang with number Kd.11.25/5/ PP.00.7/2200/2013.

On the $16^{\text {th }}$ of Ramadan 1430, which coincided with 6 September 2009, the founders had officially been donated to the world's Muslims. This institution plays a role in developing Indonesian education and even Southeast Asia. With all the abilities and potentials devoted to realizing this mission. This is further emphasized by the fact that Pondok Modern Tazakka is not involved in practical politics, and is not affiliated with any social organization, 
so that it can independently determine steps and have wider space in the field of education and teaching.

Pondok Modern Tazakka has two national level non-profit organizations under the auspices of the Tazakka Foundation which are devoted to community empowerment through productive utilization of zakat, infaq and waqf funds from individuals, institutions, companies and other agencies. Lazis Tazakka was founded by the Tazakka Foundation in 2008 before Pondok Modern Tazakka was established and subsequently confirmed with an Operational Decree from the Regional Office of the Ministry of Religion of Central Java Province as a National Amil Zakat Institution for Regency Level Representative with SK number 1256 in 2018; while Tazakka Wakaf was confirmed as one of the Nazhir Cash Waqf by the Central Indonesian Waqf Board (BWI) with register number: 3.3.00188 in 2018.

\section{Profile of Tazakka waqf institution}

Tazakka Waqf Institution is a waqf institution under the auspices of the Tazakka Foundation which was established in 2010, but was only confirmed in 2018 by BWI. The Tazakka waqf institution operates in the social and economic sectors with the main task of promoting the accumulation and development of waqf assets from Muslims.

The existence of the Tazakka Waqf Institution cannot be separated from the establishment of the Pondok Modern Tazakka because both of them synergize in carrying out the strategy towards the 2025 vision. In developing human resources, Pondok Modern Tazakka uses zakat, infaq and alms funds from Lazis Tazakka. As for physical development, Pondok Modern Tazakka uses waqf funds. Thus, all of the housing facilities and infrastructure needs are supported by the waqf funds collected by the Tazakka Waqf Institution.

Development of Waqf Instruments at the Pondok Modern Tazakka Batang views that zakat and waqf are inheritance of Islamic law which functions to empower the economic independence of the ummah. Therefore, Pondok Modern Tazakka determined to be the main instrument in the development of propaganda and education. The development and advancement of the pesantren with all its educational, preaching and social movements will rely on the zakat, donation, sodaqoh and waqf movements as its main instruments. 
Indonesia as a country with the largest Muslim population in the world has the potential for zakat, infaq and waqf. However, the existing potential has not been maximally managed and utilized, so that it does not have a significant impact on solving existing social issues. With the development and innovation of waqf in Islamic boarding schools, waqf can be a part of social problem solver and improving the economy of the pesantren.

To attract public awareness of waqf, Pondok Modern Tazakka has various strategies in collecting these waqf funds. The approach taken is approach program. Thus, the collected waqf funds are used in accordance with the specified waqf program or waqf auction. This is done by the Waqf Institute of Pondok Modern Tazakka of in achieving a long-term boarding school vision, that is in physical development funded by waqf funds. This is then called the empowerment of waqf to strengthen the independence of the pesantren.

\section{Waqf collection strategy}

Waqf requires a strategy in terms of collection. Likewise, what is implemented by Pondok Modern Tazakka as waqf nazhir has a strategy of collecting waqf funds which is divided into 3 stages, namely: marketing, fundraising, and coaching.

Marketing strategy is as a form of socialization and education of waqf to the community. When the community understands the virtues and principles of waqf, waqf will become a part of the people's mindset and of course when offering waqf programs it is easier to participate because waqf has become the lifestyle of the community.

An explanation of the vision, ideals and stages of the boarding school development program as part of the waqf marketing strategy is also conveyed through recitation forums or special meetings with waqifs that are routinely held in several cities: Batang, Pekalongan, Kendal, Semarang, Tegal, Jogjakarta and Jabodetabek.

Funding strategy is an effort to collect waqf from the community which is carried out through several approaches and methods:

1. Identification of potential waqf. The identification of potential waqf includes the area and the assumed potential amount of waqf. This process is important for mapping, then the pattern of guidance and education for waqf becomes right on target. 
2. Waqf cash service. In this case, Tazakka opened a waqf service counter on the veranda of the Az-Zaky Mosque and at the waqf office of the Pondok Modern Tazakka. In addition, it also opens cash waqf service counters at several recitation outlets organized by the Tazakka Foundation or which are organized in collaboration with other parties.

3. Pick-up-the-ball strategy, that is by providing waqf and zakat pick-up services for pilgrims who have not been able to deliver them to Tazakka themselves or have not been able to use other waqf services such as account transfers or auto-debit.

4. Waqf transfer service through Tazakka's waqf account. Waqf auto debit is services from bank partners that facilitate customers to automatically transfer their accounts to Tazakka's waqf accounts. This waqf auto debit program is one of the leading programs. The socialization of the account was done through Tazakka's internal printed media and other electronic media.

5. Collective waqf service, that is the existence of a group of waqf that collectively agree on waqf, both cash and non-cash (choosing one of the various waqf provided). Usually cash waqf is applied for certain waqf products.

6. Waqf saving service. It is a kind of piggy bank intended for congregants who want to distribute their waqf in the form of change. Each saving has a registration code. Pilgrims can deposit the waqf saving directly to the Tazakka waqf counter, or text the waqf pick-up service. These waqf saving is also distributed to all students and teachers of the Pondok Modern Tazakka. Its purpose is as an educational instrument for students to get used to waqf, so that waqf will become their lifestyle in the future.

7. Waqif development strategy. In addition to marketing and fundraising strategies, this strategy is done by providing continuous guidance to the waqifs who have routinely donated their assets to Tazakka so that their Islamic commitment and struggle for the people and their loyalty to Tazakka are maintained and increase. The guidance of the waqif is usually carried out through recitation forums and informal meetings. Even though the recitation materials are general (not always related to waqf and zakat), during the question and answer session or after recitation, a space is usually provided for the 
waqifs to consult and discuss various matters regarding waqf and the latest development in social conditions, apart from of course, to inform the progress of pesantren development.

\section{Principles of waqf management}

Waqf is one of the most important instruments in improving and advancing Tazakka Modern Pondok. Therefore, in advancing the lodge, a vision, values and philosophy are needed.

Vision, values, and philosophy are important for an institution or an organization. Because all of these become the souls that move the institution in achieving the programs it achieves. Without a soul, the organization or institution becomes porous and can eventually collapse. The values that animate in each of their activities are as follows:

Mandate and purpose. Tazakka Waqf is in synergy and is supported by stakeholders both from institutions and individuals who give their trust and trust to the Tazakka Waqf Institution. Trust or mandate coupled with the aspiration to build the people is an important part of efforts to mobilize community empowerment and develop social movements in order to participate in providing solutions for the nation. Thus, the key word that the Tazakka Waqf Institution always adheres to in managing the community's waqf funds is trust and ideals.

Many people are trustworthy but do not have goals. Many people have high ideals and ideals but are not mandated. Trust is honest, responsible and can carry out. As a recipient of waqf, one must also have ideals, that is, before someone wants to do waqf, the Tazakka Waqf Institution must make a thorough plan. Plans made not only for the next year, but for the next five or twenty years or even the next fifty years must have been carefully planned.

It is an absolute mandate to have for every nadhir, because without trustworthiness it is impossible for the wakif to believe again and donate their assets to nadhir. This mandate must be accompanied by aspirations in the form of long-term programs and vision and mission.

When someone wants to donate their assets to the Tazakka Waqf Institution (TWI), regardless of the amount of the assets being donated or any goods or assets to be donated, the Waqf Institution is ready with programs that can be implemented through these waqf funds. Because sometimes when people come for waqf with large 
amounts of money, many Nazirs are not ready to take advantage of the money. Moreover, if there is no mandate, it can become an area for corruption.

The sunnah of movement. In understanding the Sunnah of JIEMB | 14 Rasulullah SAW, the Tazakka Waqf Institution (TWI) does not only study in terms of words, deeds, provisions and characteristics. However, TWI interprets sunnah in terms of the Prophet's movement, namely collaboration between ulama and businessmen. As the Apostle collaborated with business friends such as Siti Khadijah, Abu Bakar, Utsman bin Affan, Abdurrahman bin Auf and other friends. This has also been done by several Islamic institutions or institutions that have survived to date such as Al-Azhar University, Al-Azhar Indonesia, NU, Muhammadiyah, Gontor and other institutions. So, Tazakka also always tries to collaborate with entrepreneurs and authorities to develop the potential of waqf.

\section{Types of waqf}

1. Cash Waqf. Cash waqf is waqf in the form of cash either through cash or transfer to Pondok Modern Tazakka as a nazhir to be used in supporting the Pondok Modern Tazakka's development program.

2. Pondok Modern Tazakka also introduced the concept of waqf through money. This is different from the type of cash waqf because the object is an asset but is paid with money through the waqf scheme. For example, Pondok Modern Tazakka wants to acquire one hectare of land. The value of one square meter is Rp. 1 million. Then there are people who want to donate Rp. $100,000,000$ for a land of one hundred square meters. This is called waqf with money, because in essence, it is land waqf but paid in the form of money.

3. Asset Waqf. Asset Waqf is waqf in the form of goods or assets, namely fixed assets, physical infrastructure, as well as pesantren facilities and infrastructure. Waqf of this type is waqf which is eternal. The forms of donated assets can be in the form of land, buildings, furniture, vehicles, generators, school desks and others.

4. Benefit Waqf. This type of waqf is in the form of the benefits of an item, production, service or benefit from an investment. This type of waqf can be eternal or temporary (muaqqot) within a certain period which is determined by the waqif to nazhir himself, although the eternal one is certainly more important. 
The benefits are properties that cannot be separated from assets that are considered valuable which can provide benefits for a person or the institution.

5. Professional Waqf. Professional waqf is waqf in the form of expertise or profession from someone to the Tazakka foundation as a nazhir. The examples of waqf from several professions are a doctor who donates his profession and time to the Pondok Modern Tazakka through the Tazakka Medical Center for the purpose of treating santri patients and the public, architects and structural experts who are represented through the design drawings and building designs at Pondok Modern Tazakka, kiai and several teachers who have also donated their profession for the pesantren. Through their professional actions, their hearts, energies and minds are all devoted to the pesantren.

6. Material Waqf is in the form of building materials such as cement, paving blocks, iron, sand, pipes, stones, ceramics, paint and other materials.

7. Transfer of Rights Waqf. Waqf is a right that is owned by a person and the right is transferred to the Pondok Modern Tazakka. The examples of transferring rights waqf are royalty rights to intellectual property (IPR), rights to marketing fees for a product/advertisement or rights to share ownership in a company. This waqf has been developed and carried out by Pondok Modern Tazakka with several Tazakka anshors who donated their shares and royalties to Pondok Modern Tazakka.

\section{Analysis of the development of waqf for strengthening the economic independence of MP Tazakka}

Waqf development has to be implemented so that it is more practical and easier for people to understand and implement it. First, we must begin from a thought or mindset that people are not objects. However, the people are the subjects, they are the doers. So it is necessary to carry out continuous socialization of waqf values and hasanah, examples of civilization, and best practical waqf in many forums. Second, the keys to waqf management, mandate and ideals/mandate and vision, are strongly held.

In the movement of waqf, it is necessary to broaden the perspective on the variety of waqf as explained in the 2004 BWI law that waqf is not only limited to fixed assets but also current assets. 
These several types of waqf have been applied by Pondok Modern Tazakka.

In empowering waqf for the independence of pesantren, the community leaders at all levels, both ulama and community leaders, must collaborate and synergize to take strategic steps in order to build the future of Indonesian civilization. There are so many things that can be empowered because Indonesia has everything. There are many natural resources and human resources, so these potentials can give maximum empowerment.

Islamic boarding schools in realizing their independence can move the creative economy. The creative economy can also be realized or supported by waqf movement or waqf-based. The pesantren does not only carry out teaching and learning movements as a place to train students' worship but it is also socio-economically strong. In fact, pesantren in Indonesia have benefited from a geographical point of view since this is a very large geographical nation and the majority of Muslims. Furthermore, how to make this waqf productive and not static? So pesantrens have to create a creative economy as a form of independence and give a positive impact. One of the benefits is that a good boarding school, both physically and in system, which is usually expensive, can be affordable through waqf.

In terms of independence through the business charity, one of the souls that underlies life at Pondok Modern Tazakka is the spirit of independence. Independency means the ability to self help. The principle of self-reliance has always been instilled in the lifestyle of the santri and pesantren life in a wider scope. This means that the Pondok Modern Tazakka as an educational institution must be able to live independently and not rely on other people or other institutions for its survival, so that there is no intervention from outside parties to the internal policies of the pesantren. One of the philosophies believed is that the pesantren is assisted because it is advanced, not because it is being helped.

Pondok Modern Tazakka also strives to become an independent pesantren. Waqf assets that have been collected must always be properly maintained, even productive. The development of waqf at Pondok Modern Tazakka is one of the five terms that must be implemented by the pesantren which are contained in khizanatullah or funding. Therefore, the pesantren must always maintain and expand the existing waqf. With the management and 
development of waqf assets, it shows that Pondok Modern Tazakka is able to manage waqf well, so that the results can be used to maintain waqf or to add new waqf assets. Therefore, a special strategy is needed in developing these waqf assets.

The productive waqf that is carried out is by cultivating the waqf lands owned by Pondok Modern Tazakka. Some of these lands are obtained by buying through a waqf scheme through money and some are obtained from waqif. If the waqf land is managed for production, it is used for planting, and if it is not productive then it is made for business units. Some of the productive waqf lands are, for example, a garden in the eastern side of the campus which is planted with sengon tree and the western part is planted with cloves. There are also rented shops, restaurants, etc.

Another form of development of waqf management is by creating charity units for the Pondok Modern Tazakka business. There are some good waqf-based partnerships, namely:

1. Indonesian Blessing Tazko Mini Market

2. Student's Cooperative of Pondok Modern Tazakka

3. Student's Canteen of Pondok Modern Tazakka

4. Laundry

5. Barber Shop

6. Telephone booths

7. The Santri Shuttle Route

8. Two-floored Lodging

9. Ahsan Herbal Chicken Resto

10. Stone Breaker, CV. Lantabur

11. KBIH Muzdalifah

12. Bakery, CV Ahsan Roti

There are also the development of waqf in the forms of a corporation, including:

1. PT. Suryaputra Mitra Sejati

2. PD. Surabradja

3. Travel Hajj Plus, Umrah \& Travel Tour PT. Anneeva Mulya Wisata

4. PT. Gaido

5. RM. Sambel Layah Cab Sroup \& Tlogosari Semarang

6. Kadilangu Batang Gas Station

\section{Review of 2015 - 2019 waqf program implementation}

In the 2011 - 2014 period, Pondok Modern Tazakka focused on physical development on a donated land area of 1.6 ha. Then, in the 
2015-2019 period, the Pondok Modern Tazakka waqf program focused more on land expansion, given that the space requirements for additional facilities and infrastructure continued to increase from year to year. The land which was originally only 1.6 ha was deemed insufficient in the context of the growth of santri and pesantren.

Table 1 shows a review of the implementation of the 2015-2019 waqf program that has been completed by Pondok Modern Tazakka. From the results of the waqf (in Table 1), the assets which are managed to become productive waqf, are cash waqf/development waqf. A portion of the development waqf is invested in a pesantren business charity which is channeled into several pesantren's business units.

In summary, some of the impacts of the results of waqf empowerment for the independence of the boarding school at the Pondok Modern Tazakka, are:

1. Creating jobs

2. Increasing human resources education

3. Teacher welfare improvement

4. Creating social and economic justice

5. Construction of infrastructure facilities

6. Reducing pesantren's operational costs

\section{Conclusion}

Few of the people today understand that waqf can build civilization, and many institutions still manage waqf only for the short term and not for the long term. Then this becomes a note for Muslim scholars and leaders to organize and manage a more designed, more structured and more massive da'wah strategy by using and optimizing zakat and waqf which ultimately is for the empowerment of Muslims. Currently, among the ummah there are still a lot of noise related to politics, culture, social and even among mass organizations, the khilfiyah problem has not been resolved so that the community has not had the opportunity to think about taking strategic steps for future civilization.

The development of various types of waqf at Pondok Modern Tazakka can make it easier for people to do waqf through 6 types of waqf, namely asset waqf, waqf through money, productive waqf, beneficial waqf, professional waqf and transfer of rights waqf.

The form of development of waqf management at Pondok Modern Tazakka is through many programs from each of the various 
types of waqf it has such as productive waqf with the establishment of several charity units and companies owned by the pesantren, namely the Tazakka Toko (Tazko) minimarket, the bakery \& cake shop, the KBIH Muzdalifah, the Ahsan Herbal Chicken Resto, travel, printing, stone breaker, etc.

The uniqueness of the development of waqf collection and management is that the community can have waqf according to the desired program and not always through fixed and current assets but also can have waqf in non-material forms such as professional waqf, beneficial waqf which of course has an impact on the economic independence of the pesantren in reducing pesantren's operational costs, absorb or reduce the level of unemployment because it creates jobs, improves human resources (students, teachers and the community) by providing scholarships, providing free health services, building infrastructure, and low cost daily expenditures for students.

\section{References}

Advani, R. (2014). Financial Freedom: A Guide to Achieving Lifelong Wealth and Security. Apress.

Ariadi, R., Malelak, M. I., \& Astuti, D. (2015). Analisa Hubungan Financial Literacy dan Demografi Dengan Investasi, Saving dan Konsumsi. Finesta, 3(1), 7-12.

Bandura, A. (1978). Self-efficacy: Toward a unifying theory of behavioral change. Advances in Behaviour Research and Therapy, 1(4), 139161. https://doi.org/10.1016/0146-6402(78)90002-4

Brandon, D. P., \& Smith, C. M. (2009). Prospective Teachers' Financial Knowledge and Teaching Self-Efficacy. Journal of Family Consumer Sciences Education, 27(1), 14-28.

Duhariadin Simbolon, "Wakaf Berjangka Dalam Perspektif Fikih dan Undang-Undang N0. 41 Tahun 2004 Serta Implikasinya Terhadap Pemberdayaan Umat", Tesis, Medan: UIN Sumatera Utara, 2016

Dwiastanti, A., \& Hidayat, W. (2016). Literasi Keuangan Ibu Rumah Tangga dalam Membentuk Perilaku Keuangan Keluarga. Prosiding SNA MK, $1-12$.

Ghazaly, A.R., Ihsan, G., \& Shidiq, S. (2015). Fiqh Muamalat. Jakarta: Penerbit Kencana. p 179.

Hafidh, Z., \& Badrudin, B. (2018). Pesantren dan Kemandirian Perekonomian: Studi tentang Kewirausahaan di Pondok Pesantren 
Ar-Risalah Cijantung IV Ciamis. Manageria: Jurnal Manajemen Pendidikan Islam, 3(2), 257-267.

Hasbullah Hilmi, "Dinamika Pengelolaan Wakaf Uang”, Disertasi, Semarang: IAIN Walisongo, 2012.

Haque, Abdul; Zulfiqar, M. (2016a). Women's Economic Empowerment through Financial Literacy, Financial Attitude and Financial Wellbeing. International Journal of Business and Social Science, 7(3), 78-88.

Haque, Abdul; Zulfiqar, M. (2016b). Women 's Economic Empowerment through Financial Literacy, Financial Attitude and Financial Wellbeing. International Journal of Business and Social Science, 7(3), 78-88.

Hofstede, G. (2001). Hofstede, Geert - Culture's consequences_ comparing values, behaviors, institutions, and organizations across nations-SAGE (2001).pdf. sage publication.

Hofstede, G. (2011). Dimensionalizing Cultures: The Hofstede Model in Context. Psychology and Culture, 2(1), 116-130. https://doi.org/10.1177/0305735616650994

Huda, M. (2012). Pengelolaan wakaf dalam perspektif fundraising: studi tentang penggalangan wakaf pada Yayasan Hasyim Asy'ari, Pondok Pesantren Tebuireng, Jombang, Yayasan Badan Wakaf, Universitas Islam Indonesia, Yogyakarta, dan Yayasan Dana Sosial Al-Falah, Surabaya. Kementerian Agama RI.

Krishna, A., Rofaida, R., \& Sari, M. (2010). Analisis Tingkat Literasi Keuangan(Survey pada Mahasiswa Universitas Pendidikan Indonesia). Proceedings of The 4th International Conference on Teacher Education; Join Conference UPI \& UPSI Bandung, Indonesia, November, 552-560.

Kumar, S., Tomar, S., \& Verma, D. (2019a). Women's financial planning for retirement: Systematic literature review and future research agenda. International Journal of Bank Marketing, 37(1), 120-141. https://doi.org/10.1108/IJBM-08-2017-0165

Kumar, S., Tomar, S., \& Verma, D. (2019b). Women's financial planning for retirement: Systematic literature review and future research agenda. International Journal of Bank Marketing, 37(1), 120-141. https://doi.org/10.1108/IJBM-08-2017-0165

Lusardi, A., \& Mitchell, O. S. (2014). The economic importance of financial literacy: Theory and evidence. Journal of Economic Literature, 52(1), 5-44. https://doi.org/10.1257/jel.52.1.5

Lusardi, A., \& Mitchelli, O. (2007). Financial literacy and retirement preparedness: Evidence and implications for financial education. 
Business $\quad$ Economics, 42(1), 35-44. https://doi.org/10.2145/20070104

Margaretha, F., \& Pambudhi, R. A. (2015). Tingkat Literasi Keuangan Pada Mahasiswa S-1. Tingkat Literasi Keuangan Pada Mahasiswa S-1 Fakultas Ekonomi, 17(1), 76-85. https://doi.org/10.9744/jmk.17.1.76.

Mubarok, J., \& Produktif, W. (2008). Simbiosa Rekatama Media.

Munir, A. S. (2015). Optimalisasi Pemberdayaan Wakaf Secara Produktif. Jurnal Ummul Qura, 6(2).

Mursyid, M. (2011). Dinamika Pesantren Dalam Perspektif Ekonomi. Millah: Jurnal Studi Agama, 11(1), 171-187.

Mustapha, M. (2015). Financial Literacy and Demographic Factors. Journal of Technology Management and Business, 2(1), 0-0.

Qahaf, M. (2006). al-Waqf al-Islami: Tatawwuruhu, Idaratuhu, Tanmiyyatuhu. Damaskus: Dar al.

Robb, C. A., \& Sharpe, D. L. (2009). Effect of personal financial knowledge on college students' credit card behavior. Journal of Financial Counseling and Planning, 20(1), 25-43.

Robbins, T., \& Mallouk, P. (2017). Unshakeable: Your Financial Freedom Playbook. Simon and Schuster.

Rozalinda (2019). Manajemen Wakaf Produktif. Depok: Raja Grafindo Persada

Saadah, N. (2018). Perencanaan Keuangan Islam Sederhana dalam Bisnis E-Commerce pada Pengguna Online Shop. Economica: Jurnal $\begin{array}{lll}\text { Ekonomi Islam, } & 9(1),\end{array}$ https://doi.org/10.21580/economica.2018.9.1.2593

Sabiq, S. (1983). Fiqh al-Sunnah, jilid II. Beirut: Dar al-Fikr.

Sina, P. G. (2013). Financial Efficacy and Financial Satisfaction: Ditinjau dari Perbedaan Gender. Journal Manajemen Institute Transformasi Indoneis - NGO, 12(2), 173-184.

Tharp, V. K., Barton, D. R., \& Sjuggerud, S. (2004). Safe strategies for financial freedom. McGraw Hill Professional.

Wahyudi, F. (2016). Manajemen Wakaf Produktif (Studi Analisis Pada Baitul Mal Di Kabupaten Kudus) (Doctoral dissertation, STAIN Kudus).

Widayat. (2010). Penentu Perilaku Berinvestasi. Ekonomika-Bisnis, 1(2), $111-128$.

Woodyard, A., \& Robb, C. (2012). Financial Knowledge and the Gender Gap. Journal of Financial Therapy, 3(1), 1-16. https://doi.org/10.4148/jft.v3i1.1453 
Subhi Mahmassani

JIEMB | 22

Journal of Islamic Economics, Management, and Business-Vol 2. No.2 (2020) 